\title{
The Evaluation of Musculoskeletal Disorders Seen in Footballers with Regard to Dominant Foot Preference
}

\author{
Halil Tanır ${ }^{1} \&$ Erkan Çetinkaya ${ }^{1}$ \\ ${ }^{1}$ Faculty of Sport Science, Aydın Adnan Menderes University, Aydın, Turkey \\ Correspondence: Halil Tanır, Faculty of Sport Science, Aydın Adnan Menderes University, Aydın, 09010, Turkey. \\ E-mail: halil.tanir@adu.edu.tr
}

Received: February 5, 2019

Accepted: February 27, 2019 Online Published: March 3, 2019

doi:10.5539/jel.v8n2p182

URL: https://doi.org/10.5539/jel.v8n2p182

\begin{abstract}
The aim of this study is to evaluate the musculoskeletal disorders observed in footballers with regard to dominant foot preference. The research sample consists of 40 volunteer male footballers with an age range of 14-18, who are students at Aydın İncirliova Sport High School in the school year of 2018-2019. "Waterloo Handedness Questionnaire Revised" developed by Elias et al. (1998) has been used in the study to determine the footballers" dominant foot preferences. The questionnaire was translated into Turkish by Özsu (2006). Musculoskeletal disorders observed in footballers have been determined by the Turkish version of the Cornell Musculoskeletal Disorders Questionnaire. The questionnaire was translated into Turkish and made practicable for Turkish users by being tested by Erdinc and et al (2011). The data were evaluated with SPSS 22.0 package program in $95 \%$ confidence range and 0.05 significance level. With the statistical analysis done in the study, it has been determined that there has been no statistically significant difference between the footballers in terms of upper extremity injuries ( $p>0.05$ ). When the injuries seen in lower extremities have been examined, it has been determined that there has been statistically significant difference in terms of injuries seen in left upper leg, left knee and left lower leg $(p<0.05)$. Within the lights of the findings obtained in the study, it has been concluded that the dominant foot preferences of the footballers have not affected the injuries seen in upper extremity but they have affected the injuries seen in some regions of the lower extremity (left upper leg, left knee and left lower leg). In addition to the known preventive precautions to avoid injuries in young footballers, it can also be recommended to strengthen sufficiently not only the dominant foot but also the non-dominant one.
\end{abstract}

Keywords: football, injury, foot preference

\section{Introduction}

Sports injuries are the etiologic loss of body function or deviation of the structure resulting from energy transfer during participation in sports (Timpka et al., 2014). Sports injuries are the circumstances which occur because of happening upon more than normal strength in one or more parts of the body due to personal and environmental factors during sporting activities. Sports injuries can adversely affect the sportsman's performance and skill level (Kolukisa et al., 2018).

The organism is muscled in different degrees during sporting activities (Gündoğdu \& Özmerdivenli, 2003). One of the most physiologically and mechanically challenging activities of organism is football. Football which is a sport that includes activities in constantly changing directions requires very good neuromuscular control, agility and eccentric/concentric strength (Van Beijsterveldt et al., 2012).

Football has become an extremely violent and aggressive game which is being played faster than in the past. In football, which has become a highly competitive sport, the frequency of injury incidences have also increased with rapid play and close contact. Nowadays, football has taken the first place among the sports branches in which sports injuries are frequently observed (Yıldız et al., 2010).

Football injury is the collective name of any kind of injury that occurs in any football activity and prevents the footballer from participating in a competition or training (Orchard \& Seward, 2002; Fuller et al., 2006). Footballers experience injuries as a result of traumas such as overloading, falling, a blow received in trainings and competitions; physiological factors such as condition, skill, agility, flexibility, lack of concentration, or environmental factors such as ground, weather, equipment, etc. (Yamaner et al., 2009). 
If a sportsman wishes to be successful, he should remain as far away as possible from injuries (Akhmedov et al., 2016). To prevent injuries is more important than treatment (Can et al., 2003). Therefore, it is highly important for sportsmen to take preventive measures. Fatigue and heavy strain in trainings and competitions, previous injuries which have not been treated completely, cold, muscle and joint stiffness due to factors such as excessive stress and infection, muscle weakness caused by an injury or lack of training, inter-muscular strength imbalance, lack of sports equipment and instruments, inadequate physical preparation, lack of warming, inappropriate sports branch for the sportsman, insufficient technique, spiritual unreadiness, extreme competition, competitive sports and consideration of diseases can be mentioned as preventive measures.

It has been foreseen that injury possibility of non-dominant foot in footballers may be more likely than dominant foot because of insufficient strength of non-dominant foot. Rahnama et al. (2005) reported that if knee flexor muscles are not strong enough, it may cause football players to injury. For this reason, it is important for football players to be evaluated from the perspective of musculoskeletal disorders by determining the dominant foot preferences of football players. Thus, possible musculoskeletal disorders can be prevented in advance by strengthening the muscular strength and endurance of the non-dominant leg.

\section{Method}

\subsection{Participant (Subject) Characteristics}

The research sample consists of 40 volunteer male footballers (age average $=16.20 \pm 0.96$ ), with a age range of 14-18, who are students at Aydın İncirliova Sport High School in the school year of 2018-2019.

\subsection{Data Collection Tools}

\subsubsection{Waterloo Handedness Questionnaire Revised}

To determine the dominant foot preferences of the players participating in the study, Waterloo Handedness Questionnaire Revised which was developed by Elias et al. (1998) has been used. The questionnaire was translated into Turkish by Özsu (2006). It consists of 10 questions. Each question is ranked as follows: always left, generally left, evenly, generally right and always right. Scoring is done as follows: always left: -2 , generally left: -1 , evenly: 0 , generally right: +1 , always right: +2 points. Based on the total score from the questionnaire, the dominance of the feet is defined according to the following points: $(-11)-(-20)$ strong left-footed, $(-1)-(-10)$ partially left-footed, $(0)$ with two legs, $(+1)-(+10)$ partially right-footed and $(+11)-(+20)$ strong right-footed.

\subsubsection{Cornell Musculoskeletal Disorders Questionnaire}

Musculoskeletal disorders seen in footballers participating in the study have been determined by the Turkish version of the Cornell Musculoskeletal Disorders Questionnaire. The Cornell Musculoskeletal Disorder Questionnaire, which was developed by the Cornell University Human Factors and Ergonomics Laboratory, becomes prominent as a useful data collection tool. The questionnaire was translated into Turkish and made practicable for Turkish users being tested by Erdinc and et al. (2001). It questions the frequency and level of the musculoskeletal disorders in 18 parts of the body and whether they hinder working capacity or not. High results indicate that musculoskeletal disorders have increased. In the questionnaire, participants are asked to mark the different pain areas or regions shown on the body. How often the participants have felt discomfort is searched with 5-point likert scale (1-Never felt, 2-Felt once-twice, 3-Felt three-four times, 4-Felt every day and 5-Felt every day several times), and pain level with 3 points likert scale (1-Mild level, 2-Middle level, 3-Extreme level). Whether these discomforts have hindered working is searched with 3 points likert scale (1-Never, 2Sometimes, 3-Most of the time).

The questionnaire can be evaluated as follows:

1) The rate of those who give responds as "I feel discomfort" in any extremity can be determined.

2) The percentages of the responses given for the regions in the lower and upper extremities can be determined.

3) Weighted score can be calculated.

Weighted score $=$ frequency* level*effect on work

a) Weighted score can be calculated for each extremity.

b) Totalising the points for the regions in the lower and upper extremities, the weighted point for the whole body can be calculated.

\subsection{Statistics and Data Analysis}

The data obtained from the questionnaire applied to evaluate the musculoskeletal disorders observed among 
footballers in terms of determination of dominant foot preference have been evaluated with SPSS 22.0 package program in $95 \%$ confidence range and 0.05 significance level. Whether the data have showed normal distribution or not has been determined by Kolmogorov-Smirnov Test. Since data have shown normal distribution, independent Sample T Test has been used to test whether there has been any difference between the two sample groups in terms of averages. Additionally, age, height, weight and Body Mass Index values such as minimal, maximum, average, midrange and standard deviation of the participants have been calculated.

\section{Results}

Table 1. Descriptive statistics regarding the footballers

\begin{tabular}{llllll}
\hline Variables & Minimum & Maximum & $\mathrm{X}$ & $\mathrm{Sd} \pm$ & Mean \\
\hline Age $($ year $)$ & 14 & 18 & 16.20 & 0.96 & 16 \\
Height $(\mathrm{cm})$ & 1.50 & 1.85 & 1.68 & 0.08 & 1.70 \\
Veight $(\mathrm{kg})$ & 45 & 80 & 59.40 & 8.56 & 59 \\
Body mass index $\left(\mathrm{kg} / \mathrm{cm}^{2}\right)$ & 17.26 & 27.68 & 20.75 & 1.91 & 20.03 \\
\hline
\end{tabular}

The descriptive statistics regarding the footballers having participated in the study have been shown in Table 1 . The age average of football players aged between 14 and 18 is $16.20 \pm 0.96$. The average length of football players is $1.68 \pm 0.08$ and while the shortest is $1.50 \mathrm{~cm}$, the longest is $1.85 \mathrm{~cm}$. Body weights of football players have varied between 45 and $80 \mathrm{~kg}$ and the average of body weights is $59.40 \pm 8.56 \mathrm{~kg}$. Body Mass Index (BMI) values of the players have ranged from 17.26 to 27.68 and the average of BMI values have been $20.75 \pm 1.91$ $\mathrm{kg} / \mathrm{cm}^{2}$.

Table 2. Comparison of footballers in terms of upper extremities according to dominant foot preferences

\begin{tabular}{|c|c|c|c|c|c|c|c|}
\hline \multirow{2}{*}{ Disorder Region } & \multirow{2}{*}{ Foot Preferences } & \multirow{2}{*}{$\mathrm{N}$} & \multirow{2}{*}{$\mathrm{X}$} & \multirow{2}{*}{$\mathrm{Sd} \pm$} & \multirow{2}{*}{$\mathrm{S}_{\text {error }}$} & \multicolumn{2}{|l|}{$\mathrm{t}$ test } \\
\hline & & & & & & $\mathrm{t}$ & $\mathrm{p}$ \\
\hline \multirow[t]{2}{*}{ Neck } & Left- footed & 12 & 1.59 & 3.18 & 0.54 & -2.973 & 0.118 \\
\hline & Right-footed & 28 & 1.62 & 14.01 & 5.71 & & \\
\hline \multirow[t]{2}{*}{ Right shoulder } & Left- footed & 12 & 1.59 & 5.34 & 0.91 & 0.849 & 0.401 \\
\hline & Right-footed & 28 & 1.67 & 3.20 & 1.30 & & \\
\hline \multirow[t]{2}{*}{ Left shoulder } & Left- footed & 12 & 1.12 & 3.85 & 0.66 & 0.703 & 0.486 \\
\hline & Right-footed & 28 & 0.00 & 0.00 & 0.00 & & \\
\hline \multirow[t]{2}{*}{ Back } & Left- footed & 12 & 2.94 & 10.52 & 1.80 & -0.621 & 0.539 \\
\hline & Right-footed & 28 & 3.10 & 14.53 & 5.93 & & \\
\hline \multirow[t]{2}{*}{ Right upper arm } & Left- footed & 12 & 0.76 & 2.51 & 0.43 & -1.546 & 0.130 \\
\hline & Right-footed & 28 & 1.67 & 4.13 & 1.68 & & \\
\hline \multirow[t]{2}{*}{ Left upper arm } & Left- footed & 12 & 1.88 & 6.54 & 1.12 & 0.572 & 0.570 \\
\hline & Right-footed & 28 & 0.33 & 0.816 & 0.33 & & \\
\hline \multirow[t]{2}{*}{ Waist } & Left- footed & 12 & 0.58 & 7.36 & 1.26 & 1.510 & 0.139 \\
\hline & Right-footed & 28 & 0.00 & 0.00 & 0.00 & & \\
\hline \multirow[t]{2}{*}{ Right forearm } & Left- footed & 12 & 2.44 & 10.25 & 1.75 & -0.231 & 0.819 \\
\hline & Right-footed & 28 & 3.50 & 11.02 & 4.50 & & \\
\hline \multirow[t]{2}{*}{ Left forearm } & Left-footed & 12 & 1.22 & 0.00 & 0.00 & -2.542 & 0.156 \\
\hline & Right-footed & 28 & 1.34 & 1.63 & 0.66 & & \\
\hline \multirow[t]{2}{*}{ Right wrist } & Left- footed & 12 & 2.03 & 5.78 & 0.99 & -0.514 & 0.610 \\
\hline & Right-footed & 28 & 3.33 & 5.31 & 2.171 & & \\
\hline \multirow[t]{2}{*}{ Left wrist } & Left- footed & 12 & 0.65 & 2.01 & 0.34 & 0.779 & 0.441 \\
\hline & Right-footed & 28 & 0.00 & 0.00 & 0.00 & & \\
\hline
\end{tabular}

There is no statistically significant difference between the left and right-footed footballers in terms of injuries seen in upper extremity $(\mathrm{p}>0.05)$. Accordingly, it can be suggested that the dominant foot preferences of football players do not affect the upper extremity injuries. 
Table 3. Comparison of footballers in terms of lower extremities according to dominant foot preferences

\begin{tabular}{|c|c|c|c|c|c|c|c|}
\hline \multirow{2}{*}{ Disorder Region } & \multirow{2}{*}{ Foot Preferences } & \multirow{2}{*}{$\mathrm{N}$} & \multirow{2}{*}{$\mathrm{X}$} & \multirow{2}{*}{$\mathrm{Sd} \pm$} & \multirow{2}{*}{$\mathrm{S}_{\text {error }}$} & \multicolumn{2}{|l|}{$\mathrm{t}$ test } \\
\hline & & & & & & $\mathrm{t}$ & $\mathrm{p}$ \\
\hline \multirow[t]{2}{*}{ Hip } & Left- footed & 12 & 4.47 & 8.94 & 1.53 & -0.223 & 0.824 \\
\hline & Right-footed & 28 & 5.33 & 7.11 & 2.90 & & \\
\hline \multirow[t]{2}{*}{ Upper right leg } & Left- footed & 12 & 12.82 & 15.12 & 2.59 & 0.825 & 0.415 \\
\hline & Right-footed & 28 & 7.33 & 14.40 & 5.88 & & \\
\hline \multirow[t]{2}{*}{ Upper left leg } & Left- footed & 12 & 1.56 & 4.95 & 0.85 & -2.076 & $0.045^{*}$ \\
\hline & Right-footed & 28 & 8.00 & 14.53 & 5.93 & & \\
\hline \multirow[t]{2}{*}{ Right knee } & Left- footed & 12 & 9.68 & 13.85 & 2.37 & -0.182 & 0.857 \\
\hline & Right-footed & 28 & 10.83 & 17.48 & 7.13 & & \\
\hline \multirow[t]{2}{*}{ Left knee } & Left- footed & 12 & 2.00 & 3.84 & 0.65 & -4.387 & $0.000 *$ \\
\hline & Right-footed & 28 & 10.33 & 6.50 & 2.65 & & \\
\hline \multirow[t]{2}{*}{ Lower right leg } & Left- footed & 12 & 9.15 & 13.21 & 2.26 & 1.426 & 0.162 \\
\hline & Right-footed & 28 & 1.33 & 3.26 & 1.33 & & \\
\hline \multirow[t]{2}{*}{ Lower left leg } & Left- footed & 12 & 1.59 & 3.06 & 0.52 & -2.179 & $0.036^{*}$ \\
\hline & Right-footed & 28 & 7.33 & 14.40 & 5.88 & & \\
\hline
\end{tabular}

Note. $*$ Significance at 0.05 level.

When the injuries observed in lower extremities have been examined, it has been determined that there has been statistically significant difference in terms of injuries observed in left upper leg, left knee and left lower leg $(\mathrm{p}<0.05)$. Accordingly, it can be suggested that right-footed footballers have experienced more injuries in left upper leg, left knee and left lower leg than left-footed footballers. No significant difference has been observed between right-footed and left-footed players in terms of injuries observed in hip, right upper leg, right knee and right lower leg regions $(\mathrm{p}>0.05)$.

\section{Discussion}

In football, which is one of the important contact sports, footballers can be frequently injured during the competition and training because of the activities such as bouncing, short distance high speed running and sliding tackle to a ball as well as tackles. Taking preventive measures to prevent footballers from getting injured is more important than treatment methods and rehabilitation after the injury. Preventive measures should be taken by determining the factors that may cause injuries especially in young footballers. Exposure to opponent's blow, inadequate warming, bad pitch conditions, unconscious and unnecessary overloading, insufficient resting between loadings, insufficient nutrition and sleep disorder can be considered as causes of injuries observed in young footballers. In addition to all these factors causing injury, football players' dominant foot preferences can cause injuries due to weakness in the non-dominant foot area. Therefore, in the study in which musculoskeletal disorders observed in young football players have been evaluated in terms of dominant foot preference, a significant difference has not been observed in terms of injuries observed in upper extremity ( $>0.05$ ). It has been thought that this condition may be caused by the injuries observed in the lower extremities in footballers. Thus, when the average values have been examined, it has been found that the upper extremity disability scores have been low and upper extremity injuries have not been observed much among footballers (Table 2).

When the average values of the lower extremity injuries have been examined, it has been seen that there have been increases in the rate of injuries (Table 3). When the literature has been examined, it has been seen that football disabilities are more likely to occur in lower extremities as this study has remarked. Bayer et al. (2017) examined the footballers who had played in 2014-2015 season of Spor Toto Super League and indicated that the rate of upper extremity injuries among these footballers was $40.1 \%$ while the rate of lower extremity injuries was $59.8 \%$. Ergün et al. (2013), in the study they examined the footballers playing in the U17 category for 3 years, determined the rate of lower extremity injuries observed in footballers to be $79.5 \%$. The distribution of upper extremity injuries according to regions was indicated as follows: femur (31.8\%), hip/groin (25\%), ankle (9.1\%), knee $(6.8 \%)$, lower leg (4.6\%) and foot (2.3\%). Koz and Ersöz (2004), in the study in which they evaluated the relationship between the flexibility and injuries in 170 footballers, having played in the 2001-2002 season, from amateur teams fighting in the second amateur group of Ankara province, found that 48 injuries $(21.6 \%)$ occurred in upper extremity (hand, arm, elbow, shoulder) and 132 injuries (59.4\%) occurred in lower extremity (knee and circumference, foot and ankle). Cromwell et al. (2000), in the study in which they evaluated the efficiency of the system of education to prevent the neuromuscular risk factors that may cause injuries in the footballers playing in U13-U18 teams, determined the rate of injuries observed in the lower extremity as $77 \%$. Bayraktar et al. 
(2011), in the study they evaluated the injuries having occurred in Turkish National Men's Football Team between January 2005 and December 2005 in terms of anatomical regions, frequency and incidence mechanism, determined that 80.6 's\% of the injuries had occurred in lower extremity and the most frequent injured region had been femur (25\%).

A statistically significant difference has been found among the footballers in terms of injuries observed in left upper leg, left knee and left lower leg regions ( $\mathrm{p}<0.05$; Table 3 ). When the average values are examined, it can be mentioned that more injuries in the left upper leg, left knee and left lower leg have been observed among the right-footed footballers than the left footed footballers. The fact that the right footed footballers' left legs are not powerful enough may cause injuries in the left upper leg, left knee and left lower leg. A similar situation happens among left-footed footballers; they can be expected to experience more injuries than right-footed ones in their right lower extremities which are thought to be weak. However, there is no significant difference between right-footed and left-footed footballers in terms of injuries observed in the right lower extremity ( $>0.05$; Table 3 ). The fact that the number of left-footed footballers is low has been thought to prevent the occurrence of significant differences between left-footed and right-footed footballers in terms of injuries observed in the right lower extremity.

Within the lights of the findings obtained in the study, it has been concluded that the dominant foot preferences of the footballers have not affected the injuries observed in upper extremity but they have affected the injuries observed in some regions of the lower extremity (left upper leg, left knee and left lower leg). Moreover, it has been understood that injuries in young footballers have mostly been seen in lower extremities. In addition to the known preventive precautions to avoid injuries in young footballers, it can also be recommended to strengthen not only the dominant foot but also the non-dominant one sufficiently.

\section{References}

Akhmedov, R., Demirhan, B., Cicıoglu, I., Canuzakov, K., Turkmen, M., \& Gunay, M. (2016). Injury by regions seen in greco-roman \& freestyle wrestling. Turkish Journal of Sport and Exercise, 18(3), 99-107.

Bayer, A., Açak, M., \& Korkmaz, M. F. (2017). Türkiye Süper Ligi takımlarının 2014-2015 sezonda görülen yaralanmaların değerlendirilmesi. Beden Eğitimi ve Spor Bilimleri Dergisi, 19(2), 29-38.

Bayraktar, B., Dinç, C., Yücesir, I., \& Evin, A. (2011). Injury evaluation of the Turkish national football team over six consecutive seasons. Turkish Journal of Trauma and Emergency Surgery, 17(4), 313-317. https://doi.org/10.5505/tjtes.2011.86836

Can, S., Gürsoy, R., Ezirmik, N., \& Dane, Ş. (2003). Beden Eğitimi ve Spor Yüksek Okullarındaki öğrencilerin karşılaştıkları spor yaralanmaları. Gazi Beden Eğitimi ve Spor Bilimleri Dergisi, 8(3), 59-64.

Cromwell, F., Walsh, J., \& Gormley, J. (2000). A pilot study examining injuries in elite gaelic footballers. British Journal of Sports Medicine, 34(2), 104-108. https://doi.org/10.1136/bjsm.34.2.104

Elias, L. J., Bryden, M. P., \& Bulman-Fleming, M. B. (1998). Footedness is a better predictor than is handedness of emotional lateralization. Neuropsychologia, 36(1), 37-43.

Erdinc, O., Hot, K., \& Ozkaya, M. (2011). Turkish version of the Cornell Musculoskeletal Discomfort Questionnaire: Cross-cultural adaptation and validation. Work, 39(3), 251-260.

Ergün, M., Denerel, H. N., Binnet, M. S., \& Ertat, K. A. (2013). Injuries in elite youth football players: A prospective three-year study. Acta Orthop Traumatol Turc, 47(5), 339-346.

Fuller, C. W., Ekstrand, J., Junge, A., Andersen, T. E., Bahr, R., Dvorak, J., ... \& Meeuwisse, W. H. (2006). Consensus statement on injury definitions and data collection procedures in studies of football (soccer) injuries. Scandinavian Journal of Medicine \& Science in Sports, 16(2), 83-92. https://doi.org/10.1111/j.1600-0838.2006.00528.x

Gündoğdu, C., \& Özmerdivenli, R. (2003). Amatör ve profesyonel futbolculardaki spor sakatlıklarının vücut kütlesi ve yaş gruplarına göre dağılımlarının analizi. Gazi Beden Eğitimi ve Spor Bilimleri Dergisi, 8(4), $58-66$.

Kolukısa, Ş., Çolak, H., \& Karakoç, S. (2018). Güreş̧ilerde spor sakatlıklarının vücut bölgelerine göre dağılımının araştırılması. Journal of Current Researches on Social Sciences, 8(1), 245-254.

Koz, M., \& Ersöz, G. (2004). Futbol oyuncularında spor yaralanmalarına etki eden faktörler ve esnekliğin önemi. Gazi Beden Eğitimi ve Spor Bilimleri Dergisi, 9(3), 13-26. 
Orchard, J., \& Seward, H. (2002). Epidemiology of injuries in the Australian Football League, seasons 19972000. British Journal of Sports Medicine, 36(1), 39-44. https://doi.org/10.1136/bjsm.36.1.39

Özsu, M. S. (2006). Temel Basketbol Becerilerinde Kullanilan El ve Ayak Tercihi ile Dominant El ve Ayak İlişkisinin Incelenmesi. Doktora Tezi, Marmara Üniversitesi, Sağlık Bilimleri Enstitüsü, Beden Eğitimi ve Spor Anabilim Dalı, İstanbul.

Rahnama, N., Lees, A., \& Bambaecichi, E. (2005). A comparison of muscle strength and flexibility between the preferred and non-preferred leg in English soccer players. Ergonomics, 48(11-14), 1568-1575. https://doi.org/10.1080/00140130500101585

Timpka, T., Jacobsson, J., Bickenbach, J., Finch, C. F., Ekberg, J., \& Nordenfelt, L. (2014). What is a sports injury? Sports Medicine, 44(4), 423-428. https://doi.org/10.1007/s40279-014-0143-4

Van Beijsterveldt, A. M., Van de Port, I. G., Krist, M. R., Schmikli, S. L., Stubbe, J. H., Frederiks, J. E., \& Backx, F. J. (2012). Effectiveness of an injury prevention programme for adult male amateur soccer players: A cluster-randomised controlled trial. British Journal of Sports Medicine, 46(16), 1114-1118. https://doi.org/10.1136/bjsports-2012-091277

Yamaner, F., İmamoğlu, O., Güllü, A., Güler, D., Gümüş, M., Akalın, C. T., \& Kartal, A. (2009). Amatör ve profesyonel futbolcuların alt ekstremite yaralanmalarının araştırılması. Genel Tip Dergisi, 19(3), 105-112.

Yıldız, M., Demirkan, A. Ç., Yıldırım, Y., Yıldırım, İ., \& Ocak, Y. (2010). Afyonkarahisar ili amatör futbol takımlarında oynayan sporcularda görülen sakatlanma sıklıkları ve nedenlerinin araştırılması. USAD, 2(2), $17-36$.

\section{Copyrights}

Copyright for this article is retained by the author, with first publication rights granted to the journal.

This is an open-access article distributed under the terms and conditions of the Creative Commons Attribution license (http://creativecommons.org/licenses/by/4.0/). 